\title{
MEMPERBAIKI KINERJA PEMASARAN MELALUI PELATIHAN KEWIRAUSAHAAN, RISET PASAR, DAN INOVASI PRODUK
}

(Survey Pada UMKM di Periangan Timur Provinsi Jawa Barat)

Oleh:

\author{
Maman Sulaeman, Hasan Fahmi Kusnandar (Politeknik Triguna Tasikmalaya) \\ Ristina Siti Sundari (Universitas Perjuangan) \\ email. mansulaeman1274@gmail.com
}

\begin{abstract}
ABSTRAK :Tujuan penelitian ini adalah mengetahui dan menganalisis perbaikan kinerja pemasaran melalui pelatihan kewirausahaan, riset pasar, dan inovasi produk pada UMKM di Priangan Timur Provinsi Jawa Barat. Metode penelitian yang digunakan adalah metode survey. Pengumpulan data diperoleh melalui kuesioner dan studi pustaka. Populasi dalam penelitian ini adalah UMKM di Periangan Timur Provinsi Jawa Barat. Penentuan sampel menggunakan random sebanyak 75 sampel dan analisis data yang digunakan adalah analisis jalur. Hasil penelitian menemukan bahwa secara parsial pelatihan kewirausahaan, riset pasar dan inovasi produk mampu memperbaiki kinerja pemasaran. Secara simultan pelatihan kewirausahaan, riset pasar dan inovasi produk dapat memperbaiki kinerja pemasaran UMKM di periangan timur provinsi Jawa Barat.
\end{abstract}

Kata Kunci : kewirausahaan, riset pasar, inovasi produk, kinerja pemasaran

\section{IMPROVING MARKETING PERFORMANCE THROUGH ENTREPRENEURSHIP TRAINING, MARKET RESEARCH AND PRODUCT INNOVATION}

(Survey at UMKM in East Priangan West Java Province)

\author{
Maman Sulaeman, Hasan Fahmi Kusnandar (Polytechnic Triguna Tasikmalaya) \\ Ristina Siti Sundari (Perjuangan University) \\ e-mail.mansulaeman1274@gmail.com
}

ABSTRACT: The purpose of this research is to know and analyze the improvement of marketing performance through entrepreneurship training, market research, and product innovation at UMKM in East Priangan West Java Province. The research method used is survey method. Data collection was obtained through questionnaires and literature study. The population in this study is MSMEs in East Java West Java. Determination of sample using random counted 75 samples and data analysis used was path analysis. The results found that partially entrepreneurial training, market research and product innovation were able to improve marketing performance. Simultaneously entrepreneurship training, market research and product innovation can improve the performance of UMKM marketing in east of West Java province.

Keywords: entrepreneurship, market research, product innovation, marketing performance 


\section{PENDAHULUAN}

UKM di Jawa Barat memiliki peran terutama dalam pembangunan ekonomi yaitu penciptaan lapangan pekerjaan dan pembentukan PDRB Jawa Barat. Jumlah UMKM yang terdapat di Jawa Barat menurut Badan Pusat Statistik mencapai 8.214.262 unit dengan jumlah sentra UMKM di Jawa Barat mencapai 138 sentra yang tersebar secara spasial di 5 wilayah yakni Cirebon, Bogor, Priangan Timur dan Barat, dan Purwakarta. Kota Banjar sebagai Kota di Jawa Barat yang paling sedikit memiliki sentra UMKM yaitu 6\%. Sentra UMKM di Kota Banjar banyak di dominasi oleh industri berbasis kedelai yaitu pembuatan tahu.

Perubahan yang begitu cepat dewasa ini, baik dalam hal teknologi, kebutuhan pelanggan dan siklus produk semakin pendek menyebabkan permasalahan serius bagi dunia usaha tak terkecuali UKM. Dengan kemajuan teknologi yang tidak dapat dibendung maka suatu produk perusahaan akan tambah berkembang sampai pada suatu titik, dimana produk tersebut nantinya akan sulit dibedakan antara satu dengan lainnya. Seperti masuknya berbagai produk sejenis yang merupakan hasil usaha menengah dalam negeri seperti tahu Cibuntu Bandung dan tahu Sumedang yang kian menjamur menambah pesaing bagi produk tahu yang dihasilkan oleh perajin tahu asal Kota Banjar.

Adanya tekanan persaingan begitu ketat yang secara langsung atau tidak langsung mempengaruhi kinerja pemasaran perusahaan. Demikian halnya dengan semakin agresifnya pelaku pasar dalam merebut porsi pasar yang menyebabkan industri tahu di sentra industri tahu Kota Banjar memandang perlu untuk menerapkan konsep pemasaran. Pemasaran berkaitan dengan kemampuan perusahaan dalam merencanakan dan melaksanakan konsep produk, harga, promosi, dan distribusi baik barang maupun jasa sedangkan pelatihan kewirausahaan dipandang sebagai sebuah seni dalam melihat tantangan dan peluang yang sedang dihadapi. Pelatihan kewirausahaan berkaitan dengan jiwa atau karakteristik personal dari pemilik perusahaan dan mewarnai perusahaan tersebut. Ketiga hal tersebut yaitu pelatihan kewirausahaan, program pemasaran, dan lingkungan tampaknya sudah menjadi satu kesatuan yang tidak terpisahkan. Ketiganya dipandang sebagai faktor yang mempengaruhi upaya perusahaan untuk meningkatkan kinerja pemasarannya.

Pimpinan perusahaan selaku top manajemen memainkan peran penting dalam menjamin suksesnya setiap program organisasi yang ditujukan untuk mencapai keunggulan kinerja pemasaran yang unggul. Untuk mencapai hal tersebut, dibutuhkan suatu budaya perusahaan yang mampu mengimplementasikan konsep pemasaran berupa pelatihan kewirausahaan (Weerawerdena, 2003:5), riset pasar (Ashikia, 2010:17), dan inovasi produk (Wahyono, 2008:117) yang telah dipandang oleh beberapa ahli sebagai kunci untuk mecapai keberhasilan organisasi pada masa yang akan datang sehingga dapat meningkatkan pemahaman terhadap pasar dan akan menghasilkan tanggapan dari pelanggan yang sesuai harapan perusahaan.

Berdasarkan isu yang disajikan pada latarbelakang, maka penelitian ini bertujuan untuk menguji bahwa pelatihan kewirausahaan, riset pasar, dan inovasi produk dapat memperbaiki kinerja pemasaran.

Kontribusi penelitian ini diharapkan pertama, memberi bukti empiris bahwa pelatihan kewirausahaan, riset pasar, dan inovasi produk dapat memperbaiki kinerja pemasaran. Kedua, memberi kontribusi pada kebijakan Usaha Mikro, Kecil, dan Menengah, dalam hal meningkatkan kinerja pemasaran dan daya saing Usaha Mikro, Kecil, dan Menengah.

Menurut Frees (2003:276) pelatihan kewirausahaan adalah kunci untuk 
meningkatkan kinerja pemasaran. Perusahaan yang pemimpinnya berorientasi wirausaha memiliki visi yang jelas dan berani untuk menghadapi risiko sehingga mampu menciptakan kinerja yang baik.

Selain jiwa wirausaha, riset pasar menjadi sumber inspirasi perusahaan dalam melakukan cara-cara inovatif serta menjadi sumber keunggulan bersaing dalam meningkatkan kinerja perusahaan menjadi lebih baik. Seorang pengusaha yang berorientasi wirausaha dan berriset pasar di dalam membangun strategi untuk mengembangkan perusahaan akan mengedepankan kepuasan konsumen, dan selalu memantau apakah produk telah sesuai atau melebihi harapan konsumen.

Menurut Kohli dan Jaworski (2010: 1-18), riset pasar merupakan budaya perusahaan yang bisa membawa pada meningkatnya kenerja pemasaran.

Nerver dan Slater (2007:35) mengemukakan temuan bahwa riset pasar berpengaruh positif terhadap kinerja pemasaran. Perusahaan yang memiliki tingkat riset pasar yang tinggi akan memiliki kinerja pemasaran yang tinggi. Hal ini karena perusahaan yang memiliki derajat riset pasar yang tinggi akan memiliki keunggulan kompetitif dalam hal; kualitas produk, kualitas pelayanan, inovasi produk dan biaya.

Selain riset pasar, inovasi juga dapat dijadikan sebagai salah satu strategi dalam mencapai keunggulan bersaing. Usaha kecil tidak cukup hanya memiliki keungggulan komparatif (comparative advantage) namun yang terpenting adalah memiliki keungggulan bersaing yang berkelanjutan (sustainable competitive advantage). Usaha kecil dituntut untuk menghasilkan produk yang memiliki daya saing yang tinggi antara lain dengan kriteria : produk yang dijual tersedia secara teratur dan sinambung, produk yang dijual harus memiliki kualitas yang baik dan seragam, dan variasi produk harus dapat disediakan sesuai dengan kebutuhan dan permintaan pasar.
Inovasi merupakan fungsi yang penting dalam manajemen, karena inovasi berhubungan dengan kinerja perusahaan. Tujuan utama dari inovasi adalah untuk memenuhi permintaan pasar sehingga produk inovasi merupakan salah satu yang dapat digunakan sebagai keunggulan bersaing bagi perusahaan. Pelanggan umumnya menginginkan produk - produk yang inovatif sesuai dengan keinginan mereka. Bagi perusahaan, keberhasilannya dalam melakukan inovasi berarti perusahaan tersebut selangkah lebih maju dibandingkan pesaingnya. Hal ini menuntut kepandaian perusahaan dalam mengenali selera pelanggannya sehingga inovasi yang dilakukannya pada akhirnya memang sesuai dengan keinginan pelanggannya. Dengan demikian inovasi harus benar - benar direncanakan dan dilakukan dengan cermat.

Hasil penelitian Halim (2010:7) menunjukkan bahwa koefisien jalur pengaruh langsung pelatihan kewirausahaan terhadap kapabilitas pemasaran perusahaan diperoleh nilai sebesar 0,301 dengan signifikansi 0,000. Hasil ini menunjukkan bahwa terdapat cukup bukti secara empiris untuk menerima hipotesis bahwa semakin kuat pelatihan kewirausahaan maka kinerja perusahaan akan semakin tinggi. Koefisien jalur bertanda positif dapat diartikan bahwa hubungan antara pelatihan kewirausahaan dengan kapabilitas pemasaran bersifat searah. Artinya bahwa semakin kuar pelatihan kewirausahaan maka semakin tinggi kapabilitas pemasaran perusahaan.

Hasil penelitian Hanifah (2010:1) menunjukkan bahwa pelatihan kewirausahaan berpengaruh terhadap kinerja pemasaran sebesar $79,94 \%$. Pelatihan kewirausahaan yang tinggi berhubungan erat dengan penggerak utama keuntungan sehingga seorang wirausahawan mempunyai kesempatan untuk mengambil keuntungan dan munculnya peluang-peluang tersebut, 
yang pada akhirnya berpengaruh positif terhadap kinerja usaha.

Riset pasar merupakan sesuatu yang penting bagi perusahaan sejalan dengan meningkatnya persaingan global dan perubahan dalam kebutuhan pelanggan dimana perusahaan menyadari bahwa mereka harus selalu dekat dengan pasarnya.

Berbagai studi menunjukkan bahwa usaha kecil yang berriset pasar akan menempatkan pasar sebagai target yang harus dilayani, dengan cara mengarahkan berbagai sumber daya yang dimiliki untuk dijadikan sebagai sumber keunggulan bersaing yang berkelanjutan dan tujuan perusahaan dicapai semata mata dengan memberi rasa puas kepada pelanggannya,dan menghasilkan kinerja pemasaran menjadi lebih baik.

Banyak penelitian yang telah dilakukan dengan tujuan untuk membuktikan apakah riset pasar menghasilkan kinerja organisasi yang unggul. Beberapa hasil penelitian telah membuktikan adanya hubungan yang kuat antara riset pasar dengan kinerja, sedangkan hasil penelitian lainnya tidak mendukung adanya hubungan positif antara riset pasar dengan kinerja organisasi. Namun pada umumnya hasil penelitian yang menguji hubungan kausal antara riset pasar dengan kinerja organisasi memberikan kesimpulan bahwa riset pasar memiliki pengaruh terhadap kinerja organisasi.

Berdasarkan hasil penelitian Setiawan (2012:5) diketahui bahwa inovasi produk berpengaruh terhadap keunggulan bersaing. Inovasi produk merupakan sesuatu yang dapat dilihat sebagai kemajuan fungsional produk yang dapat membawa produk selangkah lebih maju dibandingkan dengan produk pesaing. Apabila produk tersebut memiliki suatu kelebihan yang dipandang sebagai nilai tambah bagi konsumen. Pengembangan produk baru dan strategisnya yang lebih efektif seringkali menjadi penentu keberhasilan dan kelangsungan hidup suatu perusahaan.

Kotler (2008:65) mengemukakan bahwa: Kinerja pemasaran merupakan faktor yang umum digunakan untuk mengukur dampak dari sebuah strategi perusahaan. Strategi perusahaan selalu diarahkan untuk menghasilkan kinerja pemasaran seperti volume penjualan, porsi pasar dan tingkatpertumbuhan penjualan maupun kinerja keuangan.

Disarankan pengukurankinerja menggunakan aktivitas-aktivitas pemasaran yang menghasilkan kinerja yaitu unit yang terjual dan perputaran pelanggan.Hal ini dilakukan agar perusahaan mempunyai kinerja pemasaran yang lebih baik dibandingkan pesaingnya.

Kerangka pemikiran dari penelitian ini adalah:

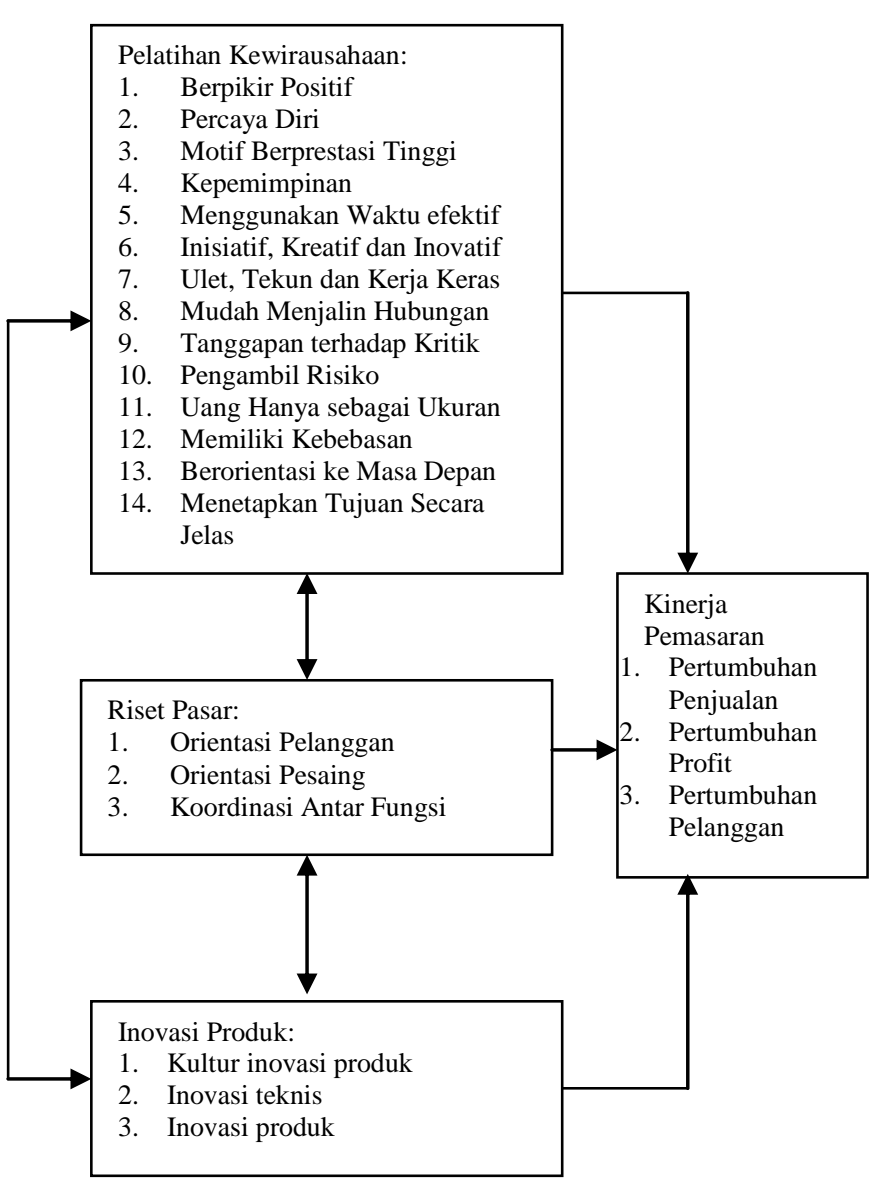




\section{METODE PENELITIAN}

Metode penelitian yang digunakan dalam penelitian ini adalah metode penelitian survey. Pada penelitian ini dijelaskan bagaimana produsen tahu melakukan kewirausahaan, bagaimana produsen melakukan riset pasar, bagaimana produsen melakukan inovasi produk, dan kinerja pemasarannya, hal ini perlu bagi perusahaan yang bersangkutan karena pelatihan kewirausahaan, riset pasar, dan inovasi produk merupakan strategi pemasaran untuk meningkatkan kinerja pemasaran.

Populasi pada penelitian ini adalah seluruh pemilik industri tahu di Sentra Industri Tahu Kota Banjar yaitu 75 orang. Pengambilan sampel dilakukan dengan metode pengambilan sampel jenuh (sampling jenuh). Pengambilan sampel secara jenuh dilakukan karena jumlah populasi hanya 75 orang.

Variabel yang dioperasionalkan yaitu sebagai berikut :

1. Variabel Independen (X)

Yaitu variabel yang keberadaannya tidak dipengaruhi dan tidak tergantung kepada variabel lain atau variabel yang berdiri sendiri. Variabel independen dalam penelitian ini adalah pelatihan kewirausahaan, riset pasar, dan inovasi produk.

a. Pelatihan kewirausahaan (X1) yaitu kemampuan kreatif dan inovatif yang dijadikan dasar, dan sumber daya untuk mencari peluang menuju kesuksesan. Ada 14 indikator untuk mengukur pelatihan kewirausahaan dalam penelitian ini:

1) Berpikir Positif.

2) Percaya Diri

3) Motif Berprestasi Tinggi

4) Kepemimpinan

5) Menggunakan Waktu dengan efektif

6) Mengambil Prakarsa (Inisiatif), Kreatif dan Inovatif

7) Ulet, Tekun dan Kerja Keras serta Dapat Memanaje Kegagalan

8) Mudah Menjalin Hubungan
9) Tanggapan terhadap Kritik, Saran dan Gagasan Baru

10) Pengambil Risiko

11) Uang Hanya sebagai Ukuran Keberhasilan,

12) Memiliki Kebebasan dan Fleksibel,

13) Berorientasi ke Masa Depan,

14) Menetapkan Tujuan Secara Jelas dan Terukur,

b. Riset pasar (X2) yaitu suatu proses dan aktivitas yang berhubungan dengan penciptaan dan pemuasan pelanggan dengan cara terus menilai kebutuhan dan keinginan pelanggan yang meliputi:

1) Orientasi pelanggan.

2) Orientasi pesaing.

3) Koordinasi antar fungsi.

c. Inovasi Produk (X3) yaitu suatu terobosan yang berkaitan dengan penciptaan produk-produk baru yang meliputi:

1) Kultur inovasi produk

2) Inovasi teknis.

3) Inovasi produk.

2. Variabel Dependen (Y)

Yaitu suatu variabel terkait atau tidak bebas atau dengan kata lain variabel yang dipengaruhi oleh variabel independen atau variabel lain. Adapun yang berfungsi sebagai variabel dependen dalam penelitian ini adalah kinerja pemasaran yaitu faktor yang seringkali digunakan untuk mengukur dampak dari strategi yang diterapkan perusahaan dipandang dari aspek pemasarannya.

Indikatornya :

a. Pertumbuhan penjualan.

b. Pertumbuhan Profit.

c. Pertumbuhan pelanggan.

Instrumen yang digunakan adalah kuesioner. Hasil uji validitas dilakukan sebanyak 2 kali pengujian pada 30 orang dan hasil pengujian kedua menunjukkan semua pernyataan valid yaitu:

1. Pernyataan tentang pelatihan kewirausahaan mempunyai $\mathrm{r}$ hitung 
antara 0,441 sampai dengan $0,817>\mathrm{r}$ tabel 0,374.

2. Pernyataan tentang riset pasar mempunyai $r$ hitung antara 0,561 sampai dengan $0,886>\mathrm{r}$ tabel 0,374

3. Pernyataan tentang inovasi produk mempunyai $r$ hitung antara 0,512 sampai dengan $0,703>\mathrm{r}$ tabel 0,374

4. Pernyataan tentang kinerja pemasaran mempunyai $r$ hitung antara 0,919 sampai dengan 0,947 > r tabel 0,374.

Hasil uji reliabilitas menunjukkan semua pernyataan reliabel yaitu alpha cronchbach $>\mathrm{r}$ tabel 0,374.

\section{HASIL PENELITIAN DAN PEMBAHASAN}

1. Pengaruh Secara Parsial Pelatihan kewirausahaan (X1) Terhadap Kinerja Pemasaran (Y)

Untuk melihat pengaruh pelatihan kewirausahaan (X1) terhadap kinerja pemasaran (Y) berdasarkan indikatorindikator tiap variabel yang digunakan dapat dilihat pada gambar di bawah ini:

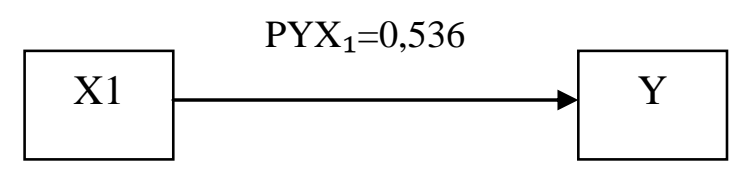

Gambar 1

Nilai Koefisien Jalur Antara Variabel X1 dan Variabel Y

Hasil penghitungan SPSS diperoleh $\mathrm{t}$ hitung $=6,134$ sedangkan $t$ tabel sebesar 1,67 dengan demikian $t_{\text {hitung }}>t_{\text {tabel }}$ sehingga dapat dikatakan bahwa terdapat pengaruh positif pelatihan kewirausahaan terhadap kinerja pemasaran.

Hasil penelitian ini mendukung penelitian sebelumnya yaitu hasil penelitian Halim (2010:7) yang menunjukkan bahwa koefisien jalur pengaruh langsung pelatihan kewirausahaan terhadap kapabilitas pemasaran perusahaan diperoleh nilai sebesar 0,301 dengan signifikansi 0,000. Hasil ini menunjukkan bahwa terdapat cukup bukti secara empiris untuk menerima hipotesis bahwa semakin kuat pelatihan kewirausahaan maka kinerja perusahaan akan semakin tinggi. Koefisien jalur bertanda positif dapat diartikan bahwa hubungan antara pelatihan kewirausahaan dengan kapabilitas pemasaran bersifat searah. Artinya bahwa semakin kuar pelatihan kewirausahaan maka semakin tinggi kapabilitas pemasaran perusahaan.

2. Pengaruh Secara Parsial Riset pasar (X2) Terhadap Kinerja Pemasaran (Y) Untuk melihat pengaruh riset pasar (X2) terhadap kinerja pemasaran (Y) berdasarkan indikator-indikator tiap variabel yang digunakan dapat dilihat pada gambar di bawah ini:

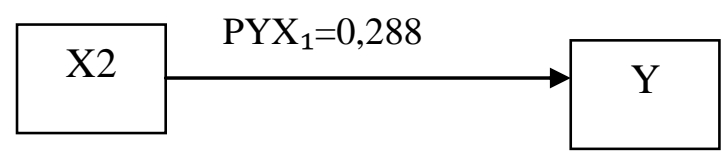

Gambar 2

Nilai Koefisien Jalur Antara Variabel X2 dan Variabel Y

Hasil penghitungan SPSS diperoleh $\mathrm{t}_{\text {hitung }}=3,172$ sedangkan $\mathrm{t}$ tabel sebesar 1,67 dengan demikian $\mathrm{t}$ hitung $>\mathrm{t}$ tabel sehingga dapat dikatakan bahwa terdapat pengaruh positif riset pasar terhadap kinerja pemasaran.

Hasil penelitian ini sesuai dengan yang dikemukakan oleh Ellis (2006:2) dalam penelitiannya yang berjudul "Market Orientation and Performance: $A$ Meta-Analysis and Cross-National Comparisons", menyatakan bahwa bukti kuantitatif bahwa pada umumnya riset pasar menentukan kinerja perusahaan. Perusahaan yang memiliki tingkat riset pasar yang tinggi akan memiliki kinerja pemasaran yang tinggi. Hal ini karena perusahaan yang memiliki derajat riset pasar yang tinggi akan memiliki keunggulan kompetitif dalam hal; kualitas produk, kualitas pelayanan, inovasi produk dan biaya.

Hasil penelitian yang dilakukan oleh Akimova (2010:1140-1141) 
membuktikan bahwa riset pasar memiliki pengaruh positif terhadap keunggulan bersaing.

Perusahaan yang menerapkan riset pasar memiliki kelebihan dalam hal pengetahuan pelanggan dan kelebihan ini dapat dijadikan sebagai sumber untuk menciptakan produk yang sesuai dengan keinginan dan kebutuhan pelanggan. Riset pasar sangat efektif dalam mendapatkan dan mempertahankan keunggulan kompetitif, yang dimulai dengan perencanaan dan koordinasi dengan semua bagian yang ada dalam organisasi untuk memuaskan kebutuhan dan keinginan konsumen. Oleh karena itu riset pasar harus menekankan pentingnya analisis kebutuhan dan keinginan target pasar secara lebih efisien dan efektif dibandingkan dengan pesaingnya dalam usaha untuk mencapai keunggulan bersaing.

Penekanan riset pasar terhadap daya saing berdasarkan pada pengidentifikasian kebutuhan pelanggan sehingga setiap perusahaan dituntut untuk dapat menjawab kebutuhan yang diinginkan konsumen baik itu melalui penciptaan produk yang baru atau pengembangan dari produk yang sudah ada, agar dapat menciptakan superior value bagi konsumennya secara berkelanjutan dan dapat menjadi modal utama bagi perusahaan untuk dapat memenangkan persaingan.

3. Pengaruh Secara Parsial Inovasi

Produk (X3) Terhadap Kinerja

Pemasaran (Y)

Untuk melihat pengaruh inovasi produk (X3) terhadap kinerja pemasaran (Y) berdasarkan indikatorindikator tiap variabel yang digunakan dapat dilihat pada gambar di bawah ini:

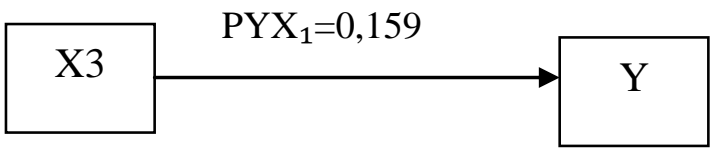

Hasil penghitungan SPSS diperoleh $\mathrm{t}$ hitung $=2,217$ sedangkan $\mathrm{t}$ tabel sebesar
1,67 dengan demikian $\mathrm{t}$ hitung $>\mathrm{t}$ tabel sehingga dapat dikatakan bahwa terdapat pengaruh positif inovasi produk terhadap kinerja pemasaran.

Hasil penelitian ini mendukung hasil penelitian Setiawan (2012:5) diketahui bahwa inovasi produk berpengaruh terhadap keunggulan bersaing. Inovasi produk merupakan sesuatu yang dapat dilihat sebagai kemajuan fungsional produk yang dapat membawa produk selangkah lebih maju dibandingkan dengan produk pesaing. Apabila produk tersebut memiliki suatu kelebihan yang dipandang sebagai nilai tambah bagi konsumen. Pengembangan produk baru dan strategisnya yang lebih efektif seringkali menjadi penentu keberhasilan dan kelangsungan hidup suatu perusahaan.

Inovasi produk yang diterapkan di sentra industri tahu adalah dengan menambah komposisi tahu dengan bahan lainnya yaitu daging sapi sehingga di hasilkan tahu jogging (tahu jerona daging) serta tahu sosis. Selain inovasi dengan menambah bahan dasar, juga dilakukan inovasi dengan penggantian mesin produksi.

Voss dan Voss dalam Setiawan (2012:6) menyebutkan bahwa:" penerapan teknologi baru merupakan faktor penentu dalam pengembangan produk baru". Keunggulan teknologi suatu produk dapat menarik minat beli konsumen untuk mengadakan pembelian pada produk baru yang dihasilkan. Dengan adanya teknologi dapat mempercepat pengembangan produk baru, kemampuan perusahaan dalam memproduksi teknologi tinggi dan produk dengan teknologi terapan sangat mempengaruhi keunggulan pada produk tersebut. Inovasi produk merupakan sesuatu yang dapat dilihat sebagai kemajuan fungsional produk yang dapat membawa produk selangkah lebih maju dibandingkan dengan produk pesaing. Apabila produk tersebut memiliki suatu kelebihan yang dipandang sebagai nilai 
tambah bagi konsumen. Pengembangan produk baru dan strategisnya yang lebih efektif seringkali menjadi penentu keberhasilan dan kelangsungan hidup suatu perusahaan, tetapi ini bukan pekerjaan yang mudah. Pengembangan produk baru memerlukan upaya, waktu dan kemampuan termasuk besarnya resiko dan biaya kegagalan.

\section{Pengaruh Secara Bersama-Sama}

Pelatihan kewirausahaan, Riset pasar,

Dan Inovasi Produk Terhadap Kinerja

\section{Pemasaran}

Besarnya pengaruh secara bersamasama pelatihan kewirausahaan (X1), riset pasar (X2) dan inovasi produk (X3) terhadap kinerja pemasaran (Y) dapat dilihat dari indikator yang digunakan masing-masing variabel dengan menggunakan path analysis.

Hasil pengolahan data melalui SPSS diperoleh hasil $\rho^{2} \mathrm{yx}_{1} \mathrm{x}_{2} \mathrm{x}_{3}$ sebesar 0,8146 atau $81,46 \%$ artinya jika pelatihan kewirausahaan, riset pasar, dan inovasi produk secara bersama-sama meningkat akan memberikan dampak positif, maka kinerja pemasaran juga akan meningkat

Secara lengkap pengaruh antara variabel pelatihan kewirausahaan (X1), riset pasar (X2), dan inovasi produk (X3) terhadap kinerja pemasaran (Y) dapat dilihat sebagai berikut:

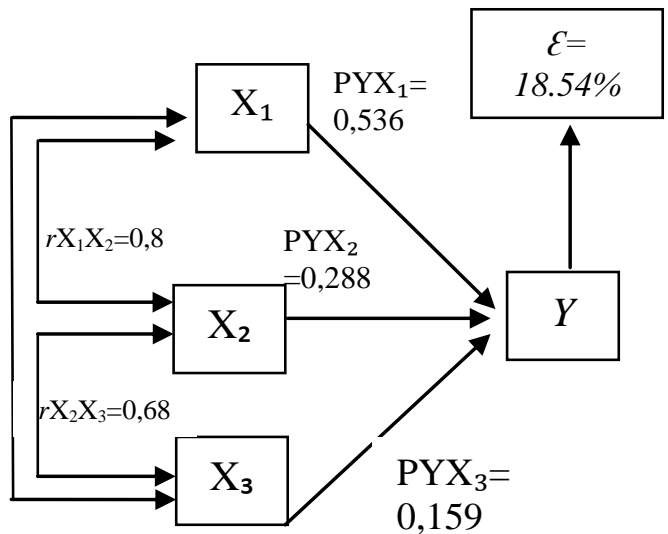

Berdasarkan hasil perhitungan diatas menunjukkan secara keseluruhan variabel pelatihan kewirausahaan (X1), riset pasar (X2), dan inovasi produk (X3) mempunyai pengaruh terhadap kinerja pemasaran (Y) sebesar 0,8146 atau $81,46 \%$ sedangkan sisanya dipengaruhi oleh variabel lain yaitu $18,54 \%$ yang tidak diteliti.

\begin{tabular}{|c|c|}
\hline Keterangan & \multirow{2}{*}{ Nilai } \\
\hline Pengaruh Pelatihan kewirausahaan $\left(\mathrm{X}_{1}\right)$ & \\
\hline $\begin{array}{l}\text { Pengaruh langsung } \mathrm{X}_{1} \text { Terhadap } \mathrm{Y}= \\
\mathrm{PYX}_{1} . \mathrm{PYX}_{1}\end{array}$ & 0,2873 \\
\hline $\begin{array}{l}\text { Pengaruh tidak langsung } \mathrm{X}_{1} \text { Terhadap } \mathrm{Y} \\
\text { melalui } \mathrm{X}_{2}=\mathrm{PYX}_{1} \cdot \mathrm{rX} 1 \mathrm{X}_{2} \cdot \mathrm{PYX}_{2}\end{array}$ & 0,1235 \\
\hline $\begin{array}{l}\text { Pengaruh tidak langsung Terhadap Y } \\
\text { melalui }\left(\mathrm{X}_{3}\right)=\mathrm{PYX}_{1} \cdot \mathrm{rX}_{1} \mathrm{X}_{3} \cdot \mathrm{PYX}_{3}\end{array}$ & 0,0555 \\
\hline Pengaruh Total $\mathrm{X}_{1}$ terhadap $\mathrm{Y}$ & 0,4663 \\
\hline \multicolumn{2}{|c|}{\begin{tabular}{|l|l} 
Pengaruh Riset pasar $\left(\mathrm{X}_{2}\right)$ & \\
\end{tabular}} \\
\hline $\begin{array}{l}\text { Pengaruh langsung } \mathrm{X}_{2} \text { Terhadap } \mathrm{Y}= \\
\mathrm{PYX}_{2} . \mathrm{PYX}_{2}\end{array}$ & 0,0829 \\
\hline $\begin{array}{l}\text { Pengaruh tidak langsung } \mathrm{X}_{2} \text { Terhadap } \mathrm{Y} \\
\text { melalui }\left(\mathrm{X}_{1}\right)=\mathrm{PYX}_{2} \cdot \mathrm{rX}_{2} \mathrm{X}_{1} \cdot \mathrm{PYX}_{1}\end{array}$ & 0,1235 \\
\hline $\begin{array}{l}\text { Pengaruh tidak langsung } \mathrm{X}_{2} \text { Terhadap } \mathrm{Y} \\
\text { melalui }\left(\mathrm{X}_{3}\right)=\mathrm{PYX}_{2} \cdot \mathrm{rX}_{2} \mathrm{X}_{3} . \mathrm{PYX}_{3}\end{array}$ & 0,0298 \\
\hline Pengaruh total $\left(\mathbf{X}_{2}\right)$ terhadap $\mathrm{Y}$ & 0,2362 \\
\hline \multicolumn{2}{|l|}{ Pengaruh Inovasi Produk $\left(\mathrm{X}_{3}\right)$} \\
\hline $\begin{array}{l}\text { Pengaruh langsung } \mathrm{X}_{3} \text { Terhadap } \mathrm{Y}= \\
\mathrm{PYX}_{3} . \mathrm{PYX}_{3}\end{array}$ & 0,0253 \\
\hline $\begin{array}{l}\text { Pengaruh tidak langsung } \mathrm{X}_{3} \text { Terhadap } \mathrm{Y} \\
\text { melalui }(\mathrm{X} 1)=\mathrm{PYX}_{3} \cdot \mathrm{rX}_{3} \mathrm{X}_{1} \cdot \mathrm{PYX}_{1}\end{array}$ & 0,0555 \\
\hline $\begin{array}{l}\text { Pengaruh tidak langsung } \mathrm{X}_{3} \text { Terhadap } \mathrm{Y} \\
\text { melalui }(\mathrm{X} 2)=\mathrm{PYX}_{3} \cdot \mathrm{rX}_{3} \mathrm{X}_{2} \cdot \mathrm{PYX}_{2}\end{array}$ & 0,0313 \\
\hline Pengaruh total $\left(\mathrm{X}_{3}\right)$ terhadap $\mathrm{Y}$ & 0,1121 \\
\hline $\begin{array}{l}\text { Pengaruh Total X1, X2, X3 secara simultan } \\
\text { terhadap Y }\end{array}$ & 0,8146 \\
\hline Pengaruh Variabel lain yang tidak diteliti & 0,1854 \\
\hline
\end{tabular}

Hasil perhitungan pada tabel diats menunjukkan bahwa pelatihan kewirausahaan berpengaruh langsung terhadap kinerja pemasaran dengan nilai sebesar 0,2873. Namun secara tidak langsung, pelatihan kewirausahaan memiliki pengaruh tidak langsung (melalui riset pasar) yang lebih kecil dengan nilai sebesar 0,1253 dan melalui inovasi produk sebesar 0,0555 sehingga dengan demikian variabel riset pasar dan inovasi produk bukan merupakan variabel intervening atau variabel yang mampu memediasi pengaruh antara variabel pelatihan kewirausahaan terhadap kinerja pemasaran. Sementara itu mengenai variabel riset pasar ternyata berpengaruh 
langsung terhadap kinerja pemasaran dengan nilai sebesar 0,0829 dan secara tidak langsung, riset pasar memiliki pengaruh tidak langsung (melalui pelatihan kewirausahaan) yang lebih besar dengan nilai sebesar 0,1235 sehingga dengan demikian variabel pelatihan kewirausahaan merupakan variabel intervening atau variabel yang mampu memediasi pengaruh antara variabel riset pasar terhadap kinerja pemasaran. Sedangkan besarnya pengaruh tidak langsung melalui inovasi produk sebesar 0,0298 lebih kecil sehingga variabel inovasi produk bukan merupakan variabel intervening atau variabel yang mampu memediasi pengaruh antara variabel riset pasar terhadap kinerja pemasaran. Selanjutnya pengaruh langsung inovasi produk terhadap kinerja pemasaran sebesar 0,0253 dan pengaruh tidak langsung melalui pelatihan kewirausahaan sebesar 0,0555 serta melalui riset pasar sebesar 0,0313 .

Adanya pengaruh secara keseluruhan variabel pelatihan kewirausahaan (X1), riset pasar (X2), dan inovasi produk (X3) mempunyai pengaruh terhadap kinerja pemasaran menunjukan bahwa keberhasilan perusahaan yang berorientasi wirausaha dan pasar sangat ditentukan oleh kemampuannya melakukan koordinasi pemasaran, aktivitas antarfungsi dalam organisasi, respon yang cepat terhadap perubahan lingkungan persaingan, dan mengantisipasi setiap perubahan strateginya.

Kewirausahaan yang diindikasikan oleh keinovasian, keproaktifan, agresif dalam bersaing dan bersikap risk taking akan mampu meningkatkan kemampuan penelitian pasar, distribusi, penentuan harga produk dan jasa, pengembangan produk, komunikasi/promosi dan pengelolaan pemasaran, sebagai indikator kapabilitas pemasaran. Riset pasar menjadi sumber inspirasi perusahaan dalam melakukan cara-cara inovatif serta menjadi sumber keunggulan bersaing dalam meningkatkan kinerja perusahaan menjadi lebih baik.

Riset pasar menjadi sumber inspirasi perusahaan dalam melakukan cara-cara inovatif serta menjadi sumber keunggulan bersaing dalam meningkatkan kinerja perusahaan menjadi lebih baik. Seorang pengusaha yang berorientasi wirausaha dan berriset pasar di dalam membangun strategi untuk mengembangkan perusahaan akan mengedepankan kepuasan konsumen, dan selalu memantau apakah produk telah sesuai atau melebihi harapan konsumen. Kemampuan perusahaan dalam menciptakan produk baru akan mempermudah perusahaan tersebut saat adaptasi dengan perubahan lingkungan, seperti menyesuaikan dengan perubahan standar produk yang ditetapkan pelanggan

\section{PENUTUP}

Berdasarkan analisis hasil penelitian dapat ditarik simpulan: bahwa pelatihan kewirausahaan, riset pasar, dan inovasi produk mamapu memperbaiki kinerja pemasaran pada UMKM di Periangan timur. Artinya jika pelatihan kewirausahaan, riset pasar, dan inovasi produk secara bersama-sama meningkat akan memberikan dampak positif, maka kinerja pemasaran juga akan meningkat.

Pelatihan kewirausahaan sudah tinggi namun perlu ditingkatkan terutama dalam kepemimpinan bahwa tidak cukup hanya faktor keturunan saja untuk jadi pemimpin tetapi perlu ditingkatkan melalui pendidikan dan pelatihan.

Riset pasar perlu ditingkatkan kembali dalam mengenali pelanggan, pesaing, dan mengoptimalkan sumber daya yang dimiliki untuk mengdapatkan kinerja pemasaran yang lebih baik. Orientasi pelanggan dapat dilakukan dengan berorietasi pada kepuasan pelanggan, dengan cara selalu mengamati perilaku pelanggan maupun mengadakan survey tentang pelanggan.

Inovasi produk perlu ditingkatkan dengan mau menerima ide - ide baru dari 
karyawannnya, menyediakan sarana dan prasarana untuk berkreasi, mengadakan pelatihan untuk mengembangkan kemampuan berkreasi. Inovasi teknis dapat dilakukan dengan cara selalu mengikuti atau memantau perkembangan teknolog.

Kinerja pemasaran perlu ditingkatkan yaitu dengan pelatihan tenaga penjualnya, membina hubungan baik dengan pelanggan. Perusahaan memperketat pengendalian kualitasnya, perusahaan memperluas jangkauan wilayah pemasarannya dengan melihat peluang peluang yang memungkinkan untuk pendistribusian produknya.

\section{DAFTAR PUSTAKA}

Akimova, Irina, 2010, Development of Market Orientation and Competitiveness of Ukrainian Firm, European Journal of Marketing.

Ellis, 2006, Market Orientation and Performance: A Meta-Analysis and Cross-National Comparisons

Frees, 2003, The Determinants of Entrepreneurial Activity, Implication for Marketing". European Journal of Marketing

Hadiyati. 2011. Pemasaran untuk UMKM (Teori dan Aplikasi), Edisi Pertama, Cetakan Pertama, Malang: Bayumedia

Halim, Abdul. 2010. Pengaruh Pelatihan kewirausahaan Terhadap Kapabilitas Pemasaran pada Sentra Industri Batik Pekalongan, Jurnal Manajemen Pemasaran

Hanifah, Amelia. 2010. Pengaruh Pelatihan kewirausahaan, Budya Organisasi Dan Strategi Bisnis Terhadap Kinerja Perusahaan (Studi Pada UMKM dI Jawa Barat), Jurnal Manajemen Pemasaran
Hartini, 2010. Peran Inovasi: Pengembangan Kualitas Produk dan Kinerja Bisnis, Fakultas Ekonomi dan Bisnis, Universitas Airlangga Surabaya Jl. Airlangga, Surabaya 60286

Jaworski,B.J., \& Kohli, A. K. 2010. Market Orientation : Antecedents and Consequences, Journal of Marketing

Kartawan, 2010. Kewirausahaan Untuk Para Calon Entrepreneur. Guardaya Intimarta Bandung

Never dan Settler, 2007. The Effect of Market Orietation on Product Innovation". Journal of Marketing

Suendro. Ginanjar, 2010. Analisis Pengaruh Inovasi Produk Melalui Kinerja Pemasaran Untuk Mencapai Keunggulan Bersaing Berkelanjutan (Studi Kasus Pada Industri Kecil Dan Menengah Batik Pekalongan) Jurnal Tesis

Uncles, 2008. Market Orientation. Australian Journal of Management. Vol.25,No.2.

Wahyono, 2008, Riset pasar dan Inovasi: Pengaruhnya Terhadap Kinerja Pemasaran, Jurnal Sains Pemasaran Indonesia, Vol.1, No.1, Mei

\section{Riwayat Penulis}

Maman Sulaeman, Penulis lahir di Jatiwangi, 12 April 1974. Penulis bekerja sebagai Dosen Tetap di Politeknik Triguna Tasikmalaya mengajar di Prodi Manajemen Perusahaan. Pendidikan yang telah ditempuh adalah Magister Manajemen dari Universitas Siliwangi lulus tahun 2013. 
